\title{
Intepretasi Lapisan Sedimen berdasarkan Ground Profile Vs dengan Pengukuran Mikrotremor di Kecamatan Pacitan
}

\author{
Nugroho Budi Wibowo ${ }^{1 *}$, Juwita Nur Sembri ${ }^{1}$, Deny Darmawan ${ }^{2}$, Yosafat \\ Sumardi ${ }^{2}$, Fitria Afriliani ${ }^{2}$, Siti Mahmudah ${ }^{2}$ \\ ${ }^{1}$ Badan Meteorologi Klimatologi dan Geofisika, Stasiun Geofisika Yogyakarta \\ ${ }^{2}$ Prodi Fisika Fakultas MIPA, Universitas Negeri Yogyakarta \\ "Email: nugrohobudiwibowo@gmail.com
}

\begin{abstract}
The thickness of sediment layer in a region can cause local site effect when earthquake occurs. The thickness of sediment layer affects the amplification. Pacitan city based on geological formation in Aluvium Formation $(Q a)$ which dominated by sediment layer. This study aims to interpret the thickness of sedimentary layer in Pacitan subdistrict based on the model of ground profile Vs by microtremor acquisition. The acquisition was conducted at 25 points in Pacitan sub-district using a portable TDS seimograph. Ground profile $V s$ result of modeling of elipticity curve shows that $V s$ value varies from $153.11 \mathrm{~m} / \mathrm{s}$ (Aluvium Formation) to $1393.48 \mathrm{~m} / \mathrm{s}$ (Andesite Breakthrough Rock Formation). The second layer of ground profile $V s$ that correlates with sediment layer is at a value of $V s<750 \mathrm{~m} / \mathrm{s}$ with areas in the Grindulu River Alluvial Plain and Pacitan Bay. The thickness of sediment layer based on the ground profile $V s$ analysis, varies from 2.59 to $94.37 \mathrm{~m}$. The thickest sediment layers are found in the Aluvium Formation $(Q a)$ with a thickness of $94.37 \mathrm{~m}$, and the thinest sediment layers are in $2.59 \mathrm{~m}$ in Jaten Formation (Tmj). Sediment layer with a thickness more than 50 $\mathrm{m}$ is located in the area of Pacitan City, Pacitan Bay and Grindulu River.
\end{abstract}

Keywords: sediment layer, ground profile, Vs, elipticity curve.

\section{ABSTRAK}

Ketebalan lapisan sedimen pada suatu wilayah dapat menyebabkan local site effect ketika terjadi gempabumi. Hal ini dikarenakan ketebalan lapisan sedimen berpengaruh terhadap amplifikasi. Kota Pacitan berdasarkan formasi geologi berada pada Formasi Aluvium ( $Q a$ ) yang didominiasi lapisan sedimen. Penelitian ini bertujuan mengintepretasi ketebalan lapisa sedimen di Kecamatan Pacitan berdasarkan model ground profile $V s$ hasil akuisisi mikrotremor. Akuisisi dilakukan pada 25 titik di Kecamatan Pacitan menggunakan seimograph portable TDS. Ground profile $V s$ hasil pemodelan elipticity curve menunjukkan bahwa nilai Vs bervariasi dari $153.11 \mathrm{~m} / \mathrm{s}$ (Formasi Aluvium) sampai $1393.48 \mathrm{~m} / \mathrm{s}$ (Formasi Batuan Terobosan Andesit). Model ground profile Vs lapisan kedua yang berkorelasi dengan lapisan sedimen berada pada nilai $V s<750 \mathrm{~m} / \mathrm{s}$ dengan area di Dataran Aluvial Sungai Grindulu dan Teluk Pacitan. Ketebalan lapisan sedimen hasil analisa ground profile $V s$, bervariasi dari 2.59 - $94.37 \mathrm{~m}$. Lapisan sedimen paling tebal terdapat pada Formasi Aluvium ( $Q a)$ dengan ketebalan 94.37 m, dan lapisan sedimen paling tipis terdapat pada Formasi Jaten (Tmj) setebal 2.59 m. Lapisan sedimen dengan ketebalan lebih dari $50 \mathrm{~m}$ berada di kawasan Kota Pacitan, Teluk Pacitan dan Sungai Grindulu.

Kata kunci: lapisan sedimen, ground profile, Vs, elipticity curve. 


\section{PENDAHULUAN}

Local site effect merupakan bahasan tentang adanya pengaruh kondisi geologi lokal daerah sekitar terhadap getaran tanah yang terjadi akibat gempabumi.Suatu wilayah dengan kondisi geologi yang sama dapat mempunyai respon yang berbeda terhadap efek getaran tanah tergantung pada sifat serta karakteristik penyusun litologi pada formasi tersebut fenomena ini disebut site effect atau site amplification ${ }^{[1]}$. Faktor amplifikasi dari gerakan horizontal dan vertikal di permukaan tanah sedimen berdasarkan pada gerakan seismik di permukaan tanah yang bersentuhan langsung dengan batuan dasar di area cekungan ${ }^{[2]}$. Salah satu faktor yang menyebabkan terjadinya local site effect ketika gempabumi adalah ketebalan lapisan sedimen pada daerah tersebut. Ketebalan lapisan sedimen juga mempengaruhi amplifikasi di daerah tersebut.Nakamura pada tahun 2000 menyatakan bahwa nilai faktor penguatan (amplifikasi) tanah berkaitan dengan perbandingan kontras impedansi lapisan permukaan dengan lapisan di bawahnya. Semakin besar perbandingan kontras impedansi kedua lapisan tersebut maka nilai faktor amplifikasinya juga semakin tinggi. Nilai amplifikasi yang tinggi berpotensi menimbulkan kerusakan pada bangunan yang ada disekitarnya. Sehingga informasi mengenai ketebalan lapisan sedimen pada suatu daerah memiliki peran yang penting dalam mitigasi bencana gempabumi. Kota Pacitan berada pada Kecamatan Pacitan dengan kondisi geologi yang didominiasi oleh lapisan sedimen berupa dataran aluvial $(Q a)$. Selain itu, secara historis Kabupaten Pacitan yang terletak di pesisir selatan Jawa Timur memiliki aktifitas seismistas yang cukup tinggi. Sehingga berdasarkan hal tersebut, penelitian ini bertujuan untuk mengintepretasi ketebalan lapisan sedimen di Kecamatan Pacitan. Pada penelitian ini, intrepretasi lapisan sedimen dilakukan berdasarkan model ground profileVs yang dihasilkan dari proses inversi kurva $\mathrm{H} / \mathrm{V}$ hasil pengukuran mikrotremor. Pengukuran mikrotremor merupakan pengukuran ambient noise yang dapat dilakukan menggunakan seperangkat seismograph. Lapisan sedimen merupakan lapisan yang dihasilkan dari proses pelapukan dan pengendapan. Sehingga lapisan ini berkorelasi dengan karakteristik tanah lunak, sedang hingga batuan lunak. Nilai $V s$ yang mendekati kategori lapisan sedimen berada pada interval $<175-750 \mathrm{~m} / \mathrm{s}$.

\section{METODE}

Penelitian ini dilakukan dengan menggunakan 25 data pengukuran mikrotremor di Kecamatan Pacitan Kabupaten Pacitan - Jawa Timur. Pengukuran mikrotremor menggunakan TDS-303 portableseismograph (gambar 3), kompas geologi, GPS, dan Laptop. Standar operasional pengukuran alat tersebut berdasarkan pada SESAME European research project ${ }^{[3]}$ dengan durasi pengukuran 30 menit untuk setiap titiknya. Mikrotremor merupakan getaran tanah dengan amplitudo pergeseran sekitar 0,1-1 $\mu \mathrm{m}$ dan amplitudo kecepatan $0,001 \mathrm{~cm} / \mathrm{s}$ sampai $0,01 \mathrm{~cm} / \mathrm{s}$. Mikrotremor periode panjang dengan periode lebih dari 1 detik terkait dengan struktur tanah yang lebih dalam yang menunjukkan dasar dari batuan keras ${ }^{[4]}$. Pengolahan data mikrotremor dengan metode HVSR untuk menghasilkan Kurva H/V. Persamaan HVSR untuk menghasilkan kurva H/V sebagai berikut:

$$
\boldsymbol{H V S R}=\frac{\sqrt{\left(\boldsymbol{A}_{(U-S)}(f)\right)^{2}+\left(\boldsymbol{A}_{(B-T)}(f)\right)^{2}}}{\left(\boldsymbol{A}_{(V)}(f)\right)} \text { dengan, } A_{(U-S)}(f) \text { adalah nilai amplitudo spektrum }
$$

frekuensi komponen Utara-Selatan, $A_{(B-T)}(f)$ adalah nilai amplitudo spektrum frekuensi komponen Barat-Timur, dan $\left(A_{(V)}(f)\right)$ niilai amplitudo spektrum frekuensi komponen vertikal. Kurva $\mathrm{H} / \mathrm{V}$ hasil perhitungan persamaan HVSR digunakan sebagai input pada metode elipticiy curve. Kurva H/Vyang digunakan sebagai input elipciticy curve seperti gambar 1 berikut: 


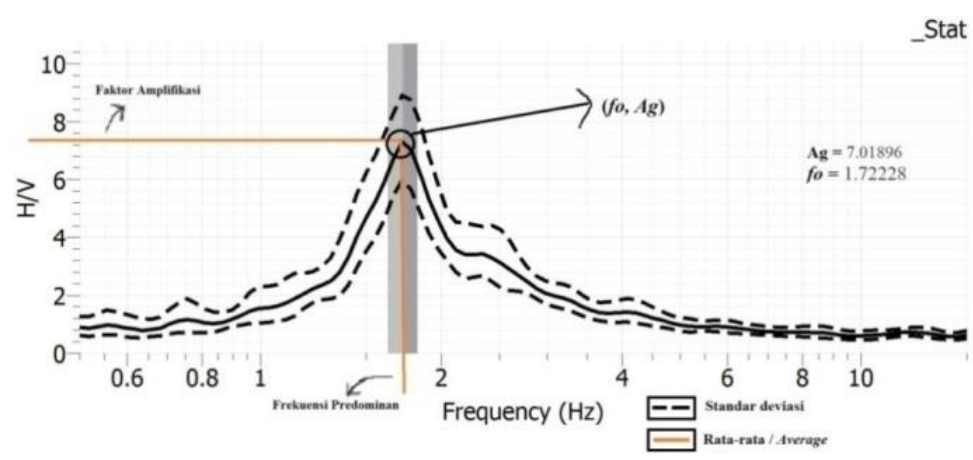

Gambar 1.(color online) Kurva HVSR sebagai Input Parameter Elipiticy Curve

Parameter input inversi selain kurva H/V antara lain paramter poisson's ratio, shear wave velocity, kecepatan gelombang primer dan density. Variasi kecepatan gelombang primer sebagai input parameter bervariasi dari $250-8202 \mathrm{~m} / \mathrm{s}^{[5]}$. Variasi poisson's ratio dari batuan sedimen bervariasi dari $0.22-0.1^{[6]}$. Ground profile Vs hasil pemodelan elipticity curve dengan misfit terendah yang akan digunakan sebagai dasar intepretasi lapisan sedimen. Perhitungan misfit berdasarkan persamaan berikut ${ }^{[7]}$ :

mis fit $=\sqrt{\frac{1}{N} \cdot \sum_{i=1}^{N}\left(\frac{D_{i}-M_{i}}{\sigma_{i}}\right)^{2}}$, dengan $N$ meruapakn titik data, $D i$ merupakan data hasil inverse dan $M i$ merupakan model struktur tanah. Ground profile yang dihasilkan dari metode elipticity curve seperti pada gambar 2. Pengolahan data menggunakan softwareNetRec, DataPro, Geopsy, Dinver dan Surfer. Kriteria lapisan sedimen mengacu pada kategorisasi klasifikasi situs berdasarkan SNI 1726-2012 ${ }^{[8]}$, seperti pada Tabel 1. Berdasarkan Tabel 1, lapisan sedimen dikategorikan untuk kelas situs $S C$ (tanah keras, sangat padat dan batuan lunak).

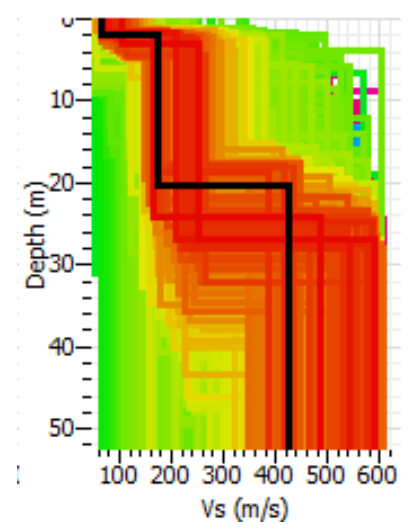

Gambar 2. (color online) Ground profile Vs hasil Metode Elipticity Curve dengan Garis Hitam merupakan Model Terbaik $^{[9]}$

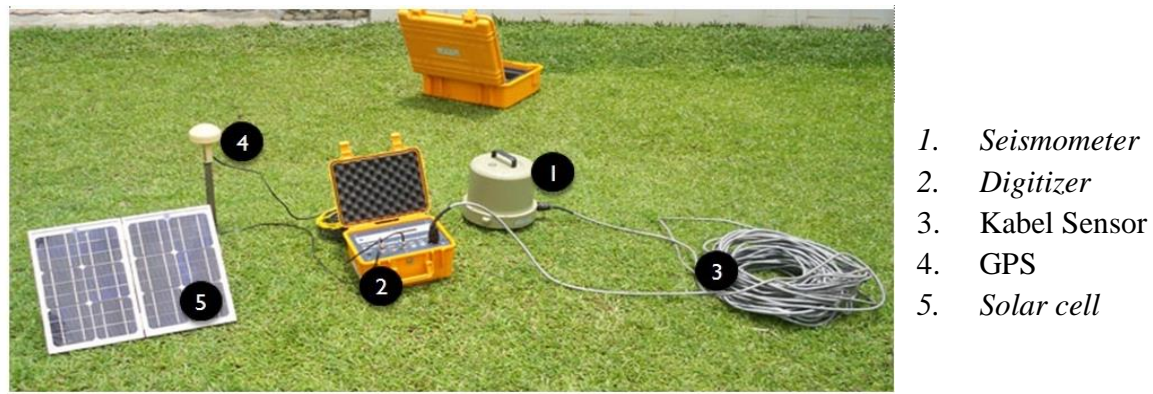

Gambar 3. (color online) Portabel Seismograph TDS 303S 
Tabel 1. Kriteria Kelas Situs berdasarkan Nilai Vs

\begin{tabular}{lc}
\hline \multicolumn{1}{c}{ Kelas Situs } & Vs (m/detik) \\
\hline$S A$ (batuan keras) & $>1500$ \\
$S B$ (batuan) & 750 sampai 1500 \\
$S C$ (tanah keras, sangat padat & 350 sampai 750 \\
dan batuan lunak) & \\
$S D$ (tanah sedang) & 175 sampai 350 \\
$S E$ (tanah lunak) & $<175$ \\
\hline
\end{tabular}

Sumber: SNI 1726-2012

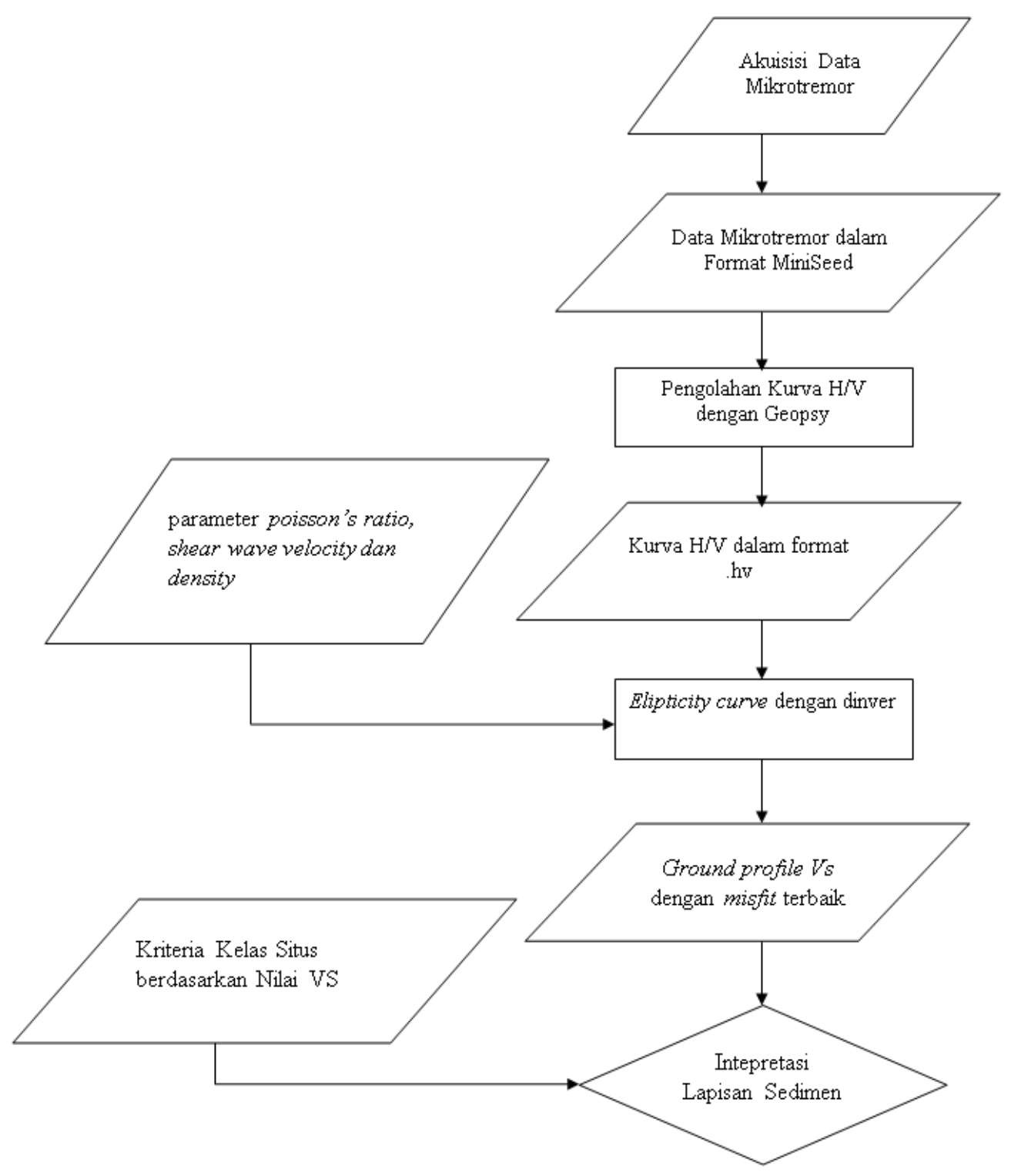

Gambar 4. Diagram Alir Penelitian 


\section{HASIL DAN PEMBAHASAN}

\section{Analisa Ground Profile Vs}

Akuisisi mikrotremor dilakukan pada 25 titik ukur yang terdapat di Kec. Pacitan. Titik ukur tersebut berada pada Formasi Aluvium (Qa), Formasi Oyo (Tmo), Batu Terobosan andesit (Tomi(an)), Formasi Wonosari (Tmwl), Formasi Arjosari (Toma), dan Formasi Jaten (Tmj). Gambar 5, menunjukkan distibusi titik ukur berdasarkan formasi geologi di Kecamatan Pacitan. Terdapat 12 titik pengukuran pada Formasi Aluvium (Qa), 2 titik pengukuran pada Formasi Jaten (Tmj), 1 titik pengukuran pada Formasi Oyo (Tmo), 4 titik pengukuran pada Formasi Wonosari (Tmwl), 5 titik pengukuran pada Formasi Arjosari (Toma) dan 1 titik pengukuran pada Batu Terobosan andesit (Tomi(an)).

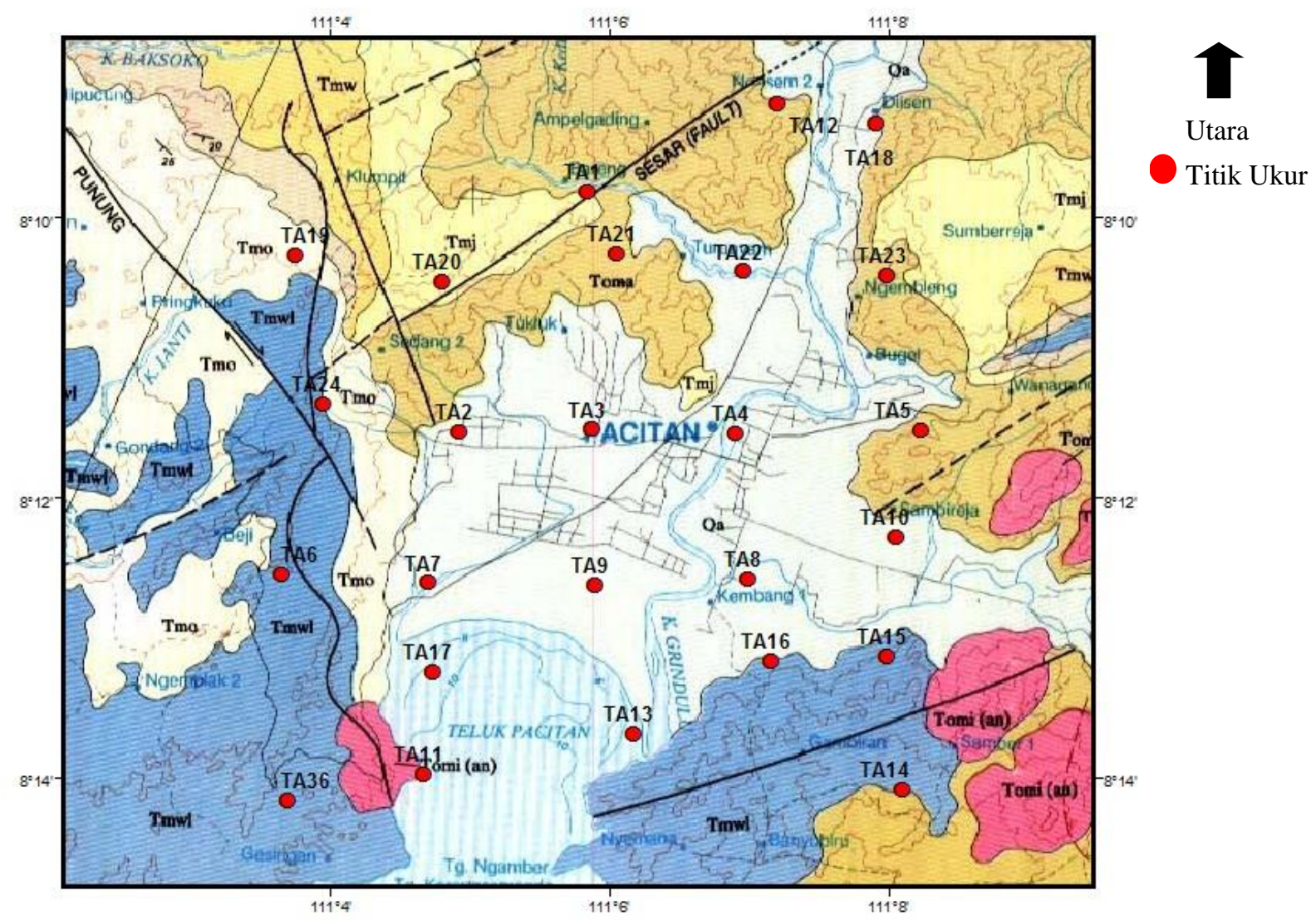

Gambar 5.(color online) Titik Ukur Mikrotremor berdasarkan Formasi Geologi di Kec. Pacitan ${ }^{[10]}$

Ground profile Vs hasil pemodelan elipticy curve menunjukkan bahwa nilai Vs bervariasi dari $153.11 \mathrm{~m} / \mathrm{s}$ (Formasi Aluvium) sampai $1393.48 \mathrm{~m} / \mathrm{s}$ (Formasi Batuan Terobosan Andesit).Gambar 6, menunjukkan model ground profile Vs pada masing - masing formasi. Pemodelan ground profileVs menggunakan tiga layer, yaitu lapisan penutup/tanah, lapisan sedimen dan batuan dasar. Ketebalan setiap lapisan pada masing - masing formasi memiliki karakter yang berbeda, formasi yang berhubungan dengan proses pengendapan memiliki lapisan tanah dan sedimen yang lebih tebal dibandingkan dengan formasi yang berhubungan dengan aktivitas pengangkatan atau gunung api. Berdasarkan Tabel 2, lapisan penutup di lokasi penelitian tidak seluruhnya berupa lapisan tanah, terdapat pula lapisan penutup berupa batuan. Hal ini sesuai dengan formasi geologi di lokasi penelitian, dimana pada Formasi Aluvium (Qa) lapisan penutup berupa tanah lunak, tanah sedang hingga tanah keras. Pada Formasi Jaten (Tmj) lapisan penutup berupa tanah keras, batuan dan batuan keras. Pada Formasi Oyo (Tmo) lapisan penutup berupa tanah keras dan padat. 
Pada Formasi Wonosari (Tmwl) lapisan penutup berupa tanah lunak, tanah sedang, tanah keras hingga batuan. Pada Formasi Arjosari (Toma) lapisan penutup berupa tanah tanah sedang hingga tanah keras. Pada Formasi Batu Terobosan Andesit (Tomi(an)) lapisan penutup berupa tanah keras hingga batuan lunak. Berdasarkan gambar 7, Kota Pacitan yang berada di Formasi Aluvial berada pada tanah penutup berupa tanah lunak hingga sedang dengan nilai Vs kurang dari $350 \mathrm{~m} / \mathrm{s}$. Nilai Vs pada tanah penutup Formasi Aluvium (Qa) bervariasi dari 153.11 - $401.69 \mathrm{~m} / \mathrm{s}$, Formasi Jaten (Tmj) bervariasi dari 349.49 - $395.56 \mathrm{~m} / \mathrm{s}$, Formasi Oyo (Tmo) $397.73 \mathrm{~m} / \mathrm{s}$, Formasi Wonosari (Tmwl) bervariasi dari 167.36 - $798.60 \mathrm{~m} / \mathrm{s}$, Formasi Arjosari (Toma) bervariasi dari 349.49 $530.18 \mathrm{~m} / \mathrm{s}$, Formasi Batu Terobosan Andesit (Tomi(an)) 729.88 m/s.
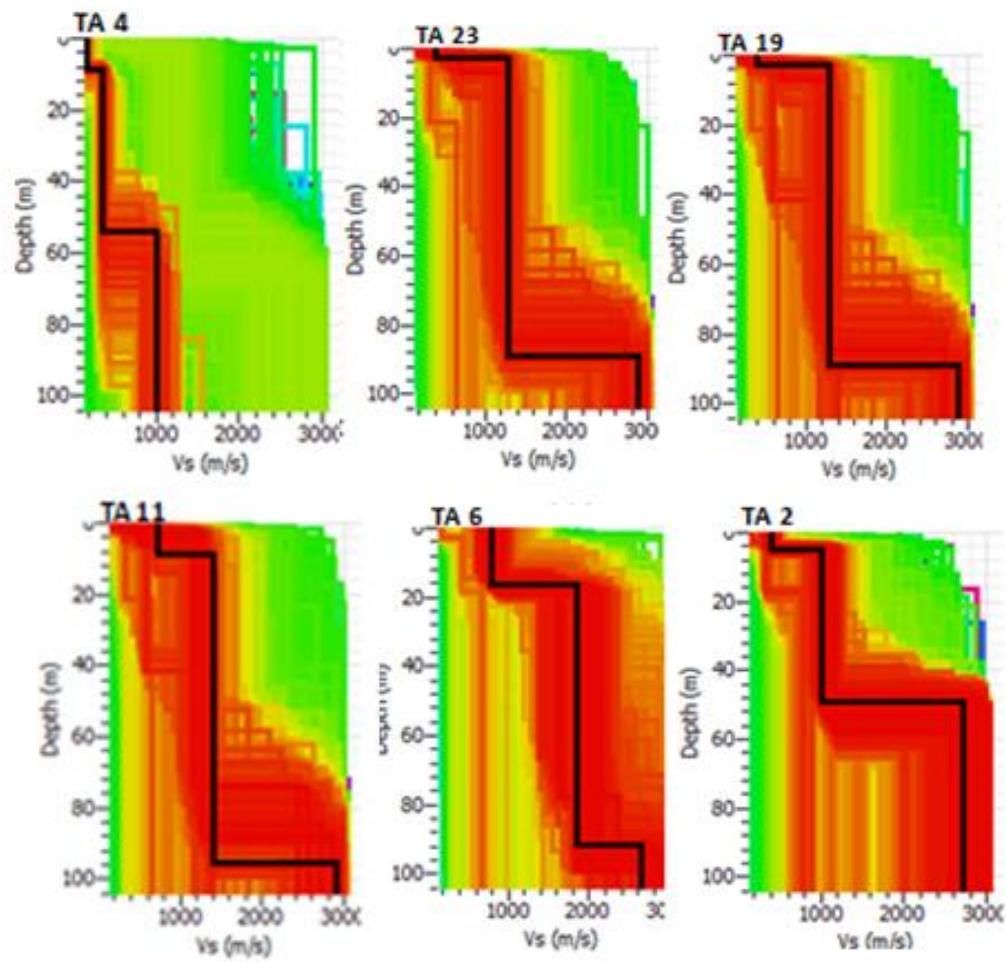

Gambar 6. (color online) Model Ground Profile Vs PadaFormasi Aluvium (TA4), Formasi Jaten (TA23), Formasi Oyo (TA19), Formasi Wonosari (TA6), Formasi Arjosari (TA2) dan Batuan Terobosan andesit (TA11)

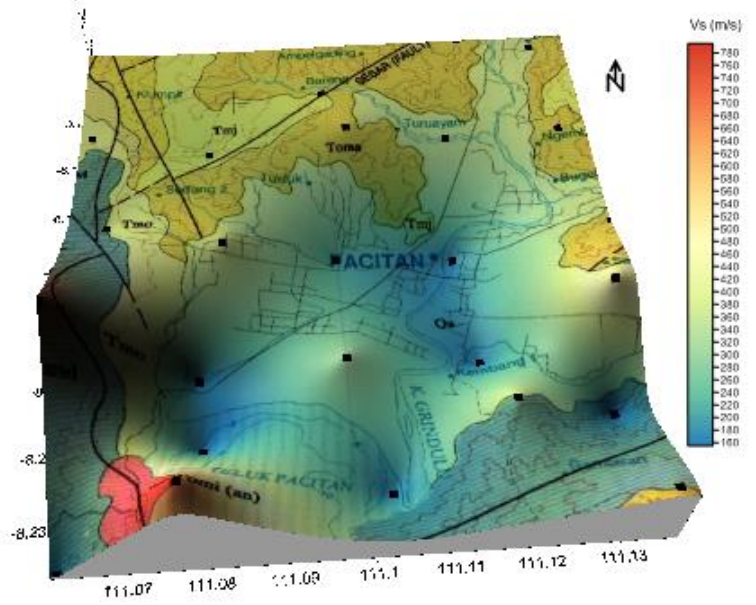

Gambar 7.(color online) Peta Variasi Nilai Vs pada Lapisan Penutup di Kecamatan Pacitan 
Tabel 2. Variasi Kedalaman, Vs dan Kategori Situs berdasarkan ground profile Vs

\begin{tabular}{|c|c|c|c|c|c|c|c|c|c|c|c|}
\hline \multirow[b]{2}{*}{ No } & \multirow{2}{*}{$\begin{array}{c}\text { Titik } \\
\text { Amat }\end{array}$} & \multicolumn{3}{|c|}{ Kedalaman (m) } & \multicolumn{3}{|c|}{ Vs $(\mathbf{m} / \mathbf{s})$} & \multirow[b]{2}{*}{ Formasi } & \multicolumn{3}{|c|}{ Kategorisasi Situs } \\
\hline & & $\begin{array}{c}\text { Lapisan } \\
1 \\
\end{array}$ & $\begin{array}{c}\text { Lapisan } \\
2 \\
\end{array}$ & $\begin{array}{c}\text { Lapisan } \\
\mathbf{3} \\
\end{array}$ & $\begin{array}{c}\text { Lapisan } \\
1 \\
\end{array}$ & $\begin{array}{c}\text { Lapisan } \\
2 \\
\end{array}$ & $\begin{array}{c}\text { Lapisan } \\
\mathbf{3} \\
\end{array}$ & & $\begin{array}{c}\text { Lapisan } \\
1 \\
\end{array}$ & $\begin{array}{c}\text { Lapisan } \\
2 \\
\end{array}$ & $\begin{array}{c}\text { Lapisan } \\
\mathbf{3} \\
\end{array}$ \\
\hline 1 & TA 3 & 4.62 & 48.94 & 103.79 & 208.43 & 448.43 & 1089.01 & Qa & $S D$ & $S C$ & $S B$ \\
\hline 2 & TA 4 & 8.49 & 54.06 & 104.15 & 164.04 & 363.655 & 1003.49 & Qa & $S E$ & $S C$ & $S B$ \\
\hline 3 & TA 5 & 2.60 & 88.91 & 104.15 & 397.73 & 1286.81 & 2881.11 & Qa & $S C$ & $S B$ & $S A$ \\
\hline 4 & TA 7 & 7.10 & 55.19 & 103.61 & 158.08 & 298.77 & 717.83 & Qa & $S E$ & $S D$ & $S B$ \\
\hline 5 & TA 8 & 2.17 & 10.47 & 104.00 & 153.11 & 335.88 & 520.41 & Qa & $S E$ & $S D$ & $S C$ \\
\hline 6 & TA 9 & 18.00 & 94.37 & 104.08 & 313.51 & 723.32 & 1586.54 & Qa & $S D$ & $S C$ & $S A$ \\
\hline 7 & TA 12 & 5.01 & 48.94 & 104.15 & 401.66 & 1003.43 & 2714.53 & Qa & $S C$ & $S B$ & $S A$ \\
\hline 8 & TA 13 & 11.30 & 65.31 & 103.82 & 158.47 & 402 & 997.36 & $\mathrm{Qa}$ & $S E$ & $S C$ & $S B$ \\
\hline 9 & TA 15 & 2.16 & 10.47 & 104.14 & 153.15 & 335.83 & 520.20 & Qa & $S E$ & $S D$ & $S C$ \\
\hline 10 & TA 16 & 5.01 & 48.94 & 103.93 & 401.69 & 1003.54 & 2720.50 & Qa & $S C$ & $S B$ & $S A$ \\
\hline 11 & TA 17 & 7.92 & 47.03 & 103.95 & 153.92 & 303.73 & 745.08 & Qa & $S E$ & $S D$ & $S C$ \\
\hline 12 & TA 18 & 2.60 & 88.91 & 103.53 & 397.77 & 1287.41 & 2880.87 & Qa & $S C$ & $S B$ & $S A$ \\
\hline 13 & TA 20 & 8.16 & 98.21 & 103.89 & 349.49 & 847.53 & 2074.92 & Tmj & $S C$ & $S B$ & $S A$ \\
\hline 14 & TA 23 & 2.59 & 88.91 & 104.09 & 395.56 & 1286.8 & 2881.15 & Tmj & $S C$ & $S B$ & $S A$ \\
\hline 15 & TA 19 & 2.60 & 88.91 & 104.15 & 397.73 & 1286.80 & 2881.00 & Tmo & $S C$ & $S B$ & $S A$ \\
\hline 16 & TA 6 & 16.22 & 91.60 & 104.15 & 798.60 & 1859.96 & 2634.20 & Tmwl & $S B$ & $S A$ & $S A$ \\
\hline 17 & TA 14 & 11.10 & 77.34 & 104.15 & 532.85 & 1325.98 & 2969.17 & Tmwl & $S C$ & $S B$ & $S A$ \\
\hline 18 & TA 24 & 2.60 & 88.91 & 104.15 & 397.72 & 1286.81 & 2881.05 & Tmwl & $S C$ & $S B$ & $S A$ \\
\hline 19 & TA 36 & 2.90 & 16.22 & 104.15 & 167.36 & 325.99 & 694.44 & Tmwl & $S E$ & $S D$ & $S C$ \\
\hline 20 & TA 1 & 4.91 & 48.94 & 104.03 & 393.79 & 1003.42 & 2714.10 & Toma & $S D$ & $S B$ & $S A$ \\
\hline 21 & TA 2 & 5.01 & 48.94 & 104.15 & 401.62 & 1003.29 & 2714.23 & Toma & $S C$ & $S B$ & $S A$ \\
\hline 22 & TA 10 & 11.11 & 77.35 & 104.15 & 530.18 & 1325.86 & 299.18 & Toma & $S C$ & $S B$ & $S A$ \\
\hline 23 & TA 21 & 4.40 & 51.95 & 104.15 & 393.83 & 1033.81 & 2880.96 & Toma & $S C$ & $S B$ & $S A$ \\
\hline 24 & TA 22 & 8.16 & 98.21 & 103.89 & 349.49 & 847.53 & 2074.92 & Toma & $S D$ & $S B$ & $S A$ \\
\hline 25 & TA 11 & 8.58 & 95.32 & 104.14 & 729.88 & 1393.48 & 2909.9 & Tomi(an) & $S C$ & $S B$ & $S A$ \\
\hline
\end{tabular}

Pada lapisan kedua, model ground profileVs menunjukkan variasi dari $402 \mathrm{~m} / \mathrm{s}-1.859$ $\mathrm{m} / \mathrm{s}$ berupa tanah keras, batuan lunak, batuan hingga batuan keras. Pada lapisan kedua ground profileVs yang masuk dalam kategori lapisan sedimen hanya berada pada Formasi Aluvial berupa tanah sedang dan tanah keras. Gambar 8, menunjukkan peta variasi nilai $V s$ pada lapisan kedua di Kecamatan Pacitan. Berdasarkan peta tersebut, lapisan kedua yang berkorelasi dengan lapisan sedimen berada pada nilai $V s<750 \mathrm{~m} / \mathrm{s}$ dengan area di Dataran Aluvial Sungai Grindulu dan Teluk Pacitan. Sedangkan pada lapisan ketiga, model ground 
profileVs bervariasi dari $520 \mathrm{~m} / \mathrm{s}-2.969 \mathrm{~m} / \mathrm{s}$ berupa batuan lunak hingga batuan keras. Gambar 9, menunjukkan peta variasi nilai Vs pada lapisan ketiga di Kecamatan Pacitan. Berdasarkan peta tersebut, lapisan ketiga berkorelasi dengan batuan dasar. Batuan dasar yang relatif lunak berada pada Formasi Aluvial (Qa) di kawasan Kota Pacitan. Sedangkan batuan dasar yang masuk dalam kategori batuan keras berada di Formasi Oyo (Tmo), Batu Terobosan andesit (Tomi(an)), Formasi Wonosari (Tmwl), Formasi Arjosari (Toma), dan Formasi Jaten (Tmj).

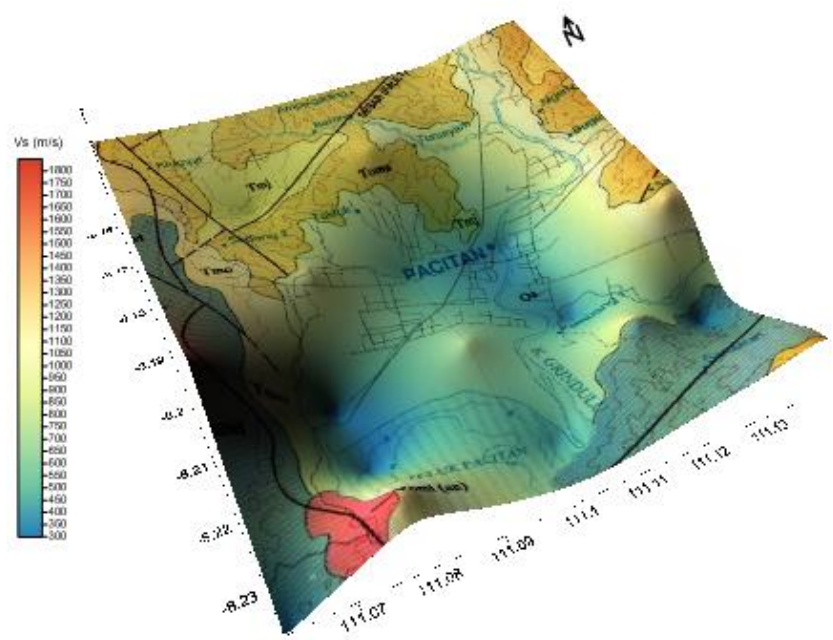

Gambar 8.(color online) Peta Variasi Nilai Vs pada Lapisan Kedua di Kecamatan Pacitan

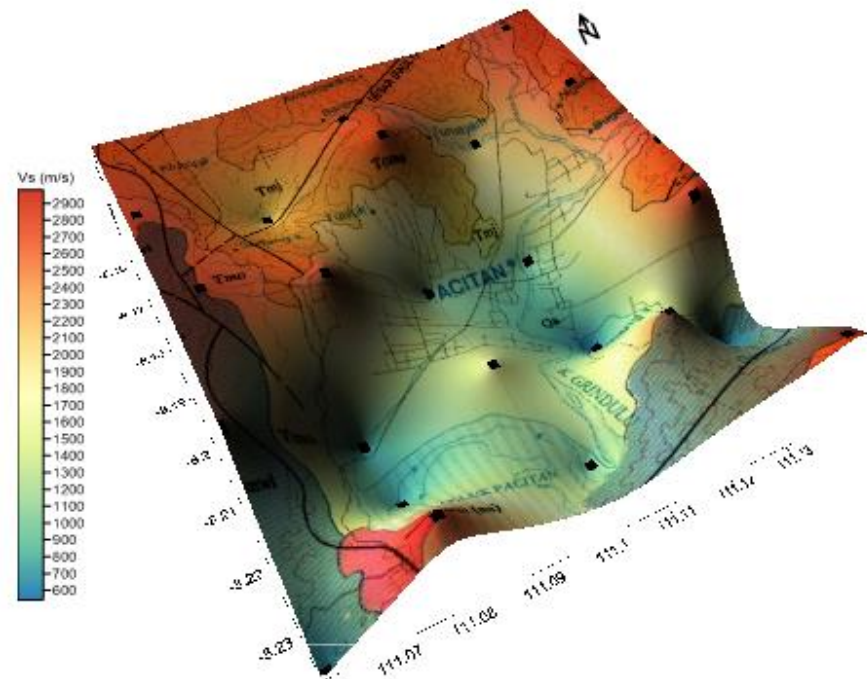

Gambar 9. (color online) Peta Variasi Nilai Vs pada Lapisan Ketiga di Kecamatan Pacitan

\section{Analisa Ketebalan Lapisan Sedimen}

Lapisan sedimen pada penilitian ini mengacu pada kategorisasi situs berdasarkan SNI 1726-2012, dimana jenis tanah yang berkorelasi dengan lapisan sedimen merupakan jenis tanah lunak $(S E)$, tanah sedang $(S D)$ dan tanah keras/padat $(S C)$. Berdasarkan Tabel 3, kategori situs yang berkorelasi dengan lapisan sedimen pada lapisan pertama terdapat pada semua lokasi titik ukur kecuali titik ukur TA 6. Meskipun demikian, lapisan sedimen dijumpai pada semua formasi pada lapisan pertama. Ketebalan lapisan sedimen pada 
lapisan pertama bervariasi dari permukaan tanah hingga kedalaman 18 meter. Pada lapisan kedua, lapisan sedimen dijumpai pada Formasi Aluvium (Qa) dan Formasi Wonosari (Tmwl) dengan kedalaman dari 10,47 m - 94,37 m. Ketebalan lapisan sedimen hasil analisa ground profile Vs, seperti Tabel 3, bervariasi dari 2.59 - $94.37 \mathrm{~m}$. Lapisan sedimen paling tebal terdapat pada Formasi Aluvium (Qa) dengan ketebalan $94.37 \mathrm{~m}$, dan lapisan sedimen paling tipis terdapat pada Formasi Jaten (Tmj) setebal $2.59 \mathrm{~m}$. Berdasarkan formasi geologi, Formasi Aluvium (Qa) memiliki ketebalan lapisan sedimen 2.60 - 94.37 m, Formasi Jaten (Tmj) memiliki ketebalan 2.59 - 8.16 m, Formasi Oyo (Tmo) dengan ketebalan 2.6 m, Formasi Wonosari (Tmwl) memiliki ketebalan 2.60 - 16.22 m, Formasi Arjosari (Toma) memiliki ketebalan 4.40 - $11.11 \mathrm{~m}$, dan Batu Terobosan andesit (Tomi(an)) dengan ketebalan $8.58 \mathrm{~m}$. Berdasarkan gambar 10, lapisan sedimen dengan ketebalan lebih dari $50 \mathrm{~m}$ berada di kawasan Kota Pacitan, Teluk Pacitan dan Sungai Grindulu. Variasi ketebalan lapisan sedimen memiliki karakteristik yang sama dengan formasi geologi. Formasi geologi yang tersusun atas material endapan maupun sedimentasi memiliki lapisan yang lebih tebal dibandingkan dengan formasi geologi yang terusun dari proses pengangkatan maupun yang lainnya. Hal ini, tercermin pada lapisan sedimen yang paling tebal terdapat pada Formasi Aluvium (Qa). Formasi Aluvium tersusun atas material endapan dan sedimentasi berupa kerakal, kerikil, pasir, lanau, lempung dan lumpur sebagai hasil endapan Sungai Grindulu dan Sungai Sundeng, serta pengaruh aktifitas marin.

Tabel 3. Ketebalan Lapisan Sedimen Analisa Ground Profile Vs di Kecamatan Pacitan

\begin{tabular}{crllrl} 
ID & $\begin{array}{c}\text { Ketebalan } \\
(\mathbf{m})\end{array}$ & Formasi & ID & $\begin{array}{c}\text { Ketebalan } \\
(\mathbf{m})\end{array}$ & Formasi \\
\hline TA3 & 48.94 & Qa & TA20 & 8.16 & Tmj \\
TA4 & 54.06 & Qa & TA23 & 2.59 & Tmj \\
TA5 & 2.60 & Qa & TA19 & 2.60 & Tmo \\
TA7 & 55.19 & Qa & TA6 & 16.22 & Tmwl \\
TA8 & 10.47 & Qa & TA14 & 11.10 & Tmwl \\
TA9 & 94.37 & Qa & TA24 & 2.60 & Tmwl \\
TA12 & 5.01 & Qa & TA36 & 16.22 & Tmwl \\
TA13 & 65.31 & Qa & TA1 & 4.91 & Toma \\
TA15 & 10.47 & Qa & TA2 & 5.01 & Toma \\
TA16 & 5.01 & Qa & TA10 & 11.11 & Toma \\
TA17 & 47.03 & Qa & TA21 & 4.40 & Toma \\
TA18 & 2.60 & Qa & TA22 & 8.16 & Toma \\
& & & TA11 & 8.58 & Tomi(an) \\
\hline
\end{tabular}




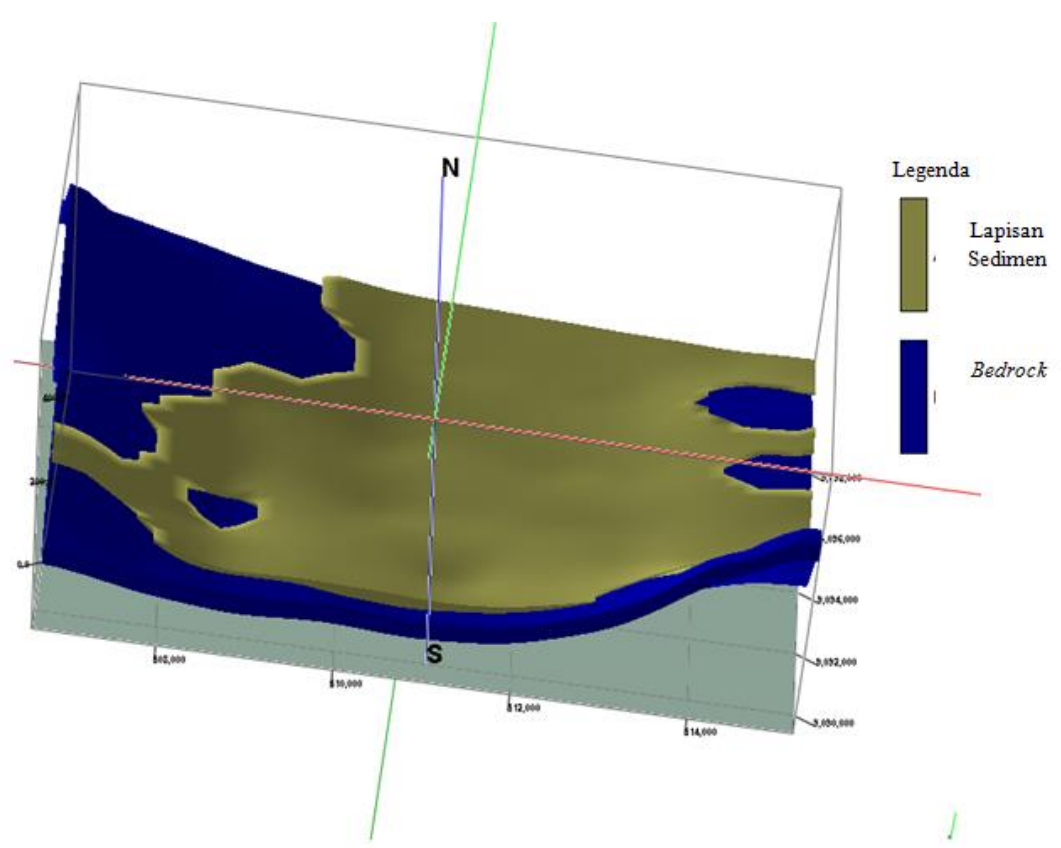

Gambar 10.(color online) Model Ketebalan Lapisan Sedimen di Kecamatan Pacitan

\section{KESIMPULAN}

Ground profile Vs hasil pemodelan elipticy curve menunjukkan bahwa nilai Vs bervariasi dari $153.11 \mathrm{~m} / \mathrm{s}$ (Formasi Aluvium) sampai $1393.48 \mathrm{~m} / \mathrm{s}$ (Formasi Batuan Terobosan Andesit). Lapisan sedimen paling tebal terdapat pada Formasi Aluvium (Qa) dengan ketebalan $94.37 \mathrm{~m}$, dan lapisan sedimen paling tipis terdapat pada Formasi Jaten (Tmj) setebal $2.59 \mathrm{~m}$. Lapisan sedimen dengan ketebalan lebih dari $50 \mathrm{~m}$ berada di kawasan Kota Pacitan, Teluk Pacitan dan Sungai Grindulu.

\section{DAFTAR PUSTAKA}

1. Nakamura, Y. 1996. Real Time Information Systems for Seismic Hazards Mitigation UrEDAS, HERAS and PIC.Railway Technical Research Institute, Quarterly Reports, 37 (3), 112-127.

2. Mirzaoglu, M. \& Dýkmen, Ü. 2003. Application of microtremors to seismic microzoning procedure. Jornal of the Balkan Geophysical Society, 6 (3), 143-156.

3. SESAME European research project WP12.2004. Guidelines for theimplementation of the $h / v$ spectral ratio technique on ambient vibrationsmeasurements, processing and interpretation.

4. Samoedra, H., Gafoer, S. \& Tjokrosapoetro, S. 1992. Peta Geologi Lembar Pacitan Jawa. Bandung: Pusat Penelitian dan Pengembangan Geologi.

5. Badan Standarisasi Nasional. 2012. Tata Cara Perencanaan Ketahanan Gempa untuk Struktur Bangunan Gedung dan Non Gedung. SNI 1726:2012. Jakarta.

6. Ostrander, W. J. 1984. Plane Wave Reflection Coefficients for Gas Sands at Nonnormal Angles of Incidence, Geophysics, 49 (10), 1637-1648.

7. Burger, H.R. 1992. Exploration Geophysics of the Shallow Subsurface. United States.

8. Novianita, A. 2009. Penggunaan Microtremor Ellipticity Curve Untuk Menentukan Struktur Lapisan Bawah Permukaan Di Daerah Yogyakarta. Skripsi. Jurusan Fisika Universitas Diponegoro. 
9. Wibowo, N. B. 2017. Ratio Model Vs30 berdasarkan Data Mikrotremor dan USGS di Kecamatan Jetis Kabupaten Bantul. J. Sains Dasar 2017, 6 (1), 49-56.

10. Hobiger,M. 2011. Polarization of surface waves: characterization, inversion and application to seismic hazard assessment. Earth Sciences. Universite Grenoble Alpes, Perancis. 